\title{
ANALISIS NORMATIF UNDANG-UNDANG NO. 1 TAHUN 2013 TENTANG LEMBAGA KEUANGAN MIKRO (LKM) ATAS STATUS BADAN HUKUM DAN PENGAWASAN BAITUL MAAL WAT TAMWIL (BMT)
}

\author{
Novita Dewi Masyithoh ${ }^{1}$
}

\begin{abstract}
Baitul Maal Wat Tamwil (BMT) has been growing rapidly in Indonesia from year to year. However, its development has still not been followed by the legal rules. Some of them follow the legal system of Cooperatives, that are Act No. 25 of 1992 and Decree of the Minister of Cooperatives and SMEs, No. 91 /KEP/M.KUKM/IX/2004 about the Implementation Guidelines for Cooperative Operations of Islamic Financial Services (KJKS). However, after Act No. 1 of 2013 about Micro-finance Institutions had been issued, the legal institutional status of BMT and its supervision has become a problem for the existence of BMT. Therefore, this study met the issues of how the legal status and supervision of BMT before and after the issued Act No. 1 of 2013 about micro-finance institutions.

This study was an empirical law rechtdogmatik against Act No. 1 of 2013 about Microfinance Institutions. It used primary legal materials, namely the Micro-finance Institutions Act; the result of interviews; and documentation that were analyzed qualitatively.

The result analysis showed that before the Law of Microfinance Institutions was issued, there were 3 groups of BMT, namely: BMT with the Cooperative legal entity and being supervised by the State Ministry of Cooperatives and SMEs; BMT that were formed under the foundations legal entity; and BMT that were formed under Non Governmental Organisation. However, after Act No. 1 of 2013 had been issued, Microfinance Institutions should only have legal status, either as a cooperative or an incorporated company (PT). In addition, the supervision should be conducted by the Financial Services Authority of Indonesia (OJK) coordinated with both the Ministry of Cooperatives and SMEs, and the Ministry of Home Affairs. Nevertheless, the competence of supervision has still not been clearly regulated in the Microfinance Institutions Act, because the new law might effectively run two years after being enacted while the implemention is also still not regulated yet.

Thus, it should be recommended to make clear implementation rules in the legal status of Microfinance Institutions, especially for those not have legal entities as well as those should
\end{abstract}

${ }^{1}$ Dosen Fakultas Syariah IAIN Walisongo Semarang

Volume V/Edisi 2/Oktober 2014 
Analisis Normatif Undang-undang No. 1 Taun 2013

transform. Similarly, in terms of supervision, there should be a clear competence of supervision performed by the FSA and the two mentioned Ministry above. So, there might not be either overlapping or loose supervision.

Keywords: Baitul Maal Wat Tamwil (BMT), Micro-finance Institutions, Law No. 1 of 2013 on Micro-finance Institutions

\section{Pendahuluan}

Baitul Maal wat Tamwil adalah lembaga keuangan dengan konsep syariah yang lahir sebagai pilihan yang menggabungkan konsep maal dan tamwil dalam satu kegiatan lembaga. Konsep maal lahir dan menjadi bagian dari kehidupan masyarakat muslim dalam hal menghimpun dan menyalurkan dana untuk zakat, infak dan shadaqah (ZIS) secara produktif. Sedangkan konsep tamwil lahir untuk kegiatan bisnis produktif yang murni untuk mendapatkan keuntungan dengan sektor masyarakat menengah ke bawah (mikro). Kehadiran BMT untuk menyerap aspirasi masyarakat muslim di tengah kegelisahan kegiatan ekonomi dengan prinsip riba, sekaligus sebagai supporting funding untuk mengembangkan kegiatan pemberdayaan usaha kecil dan menengah. Kehadiran lembaga keuangan mikro syariah yang bernama Baitul Maal wa Tamwil (BMT) dirasakan telah membawa manfaat finansil bagi masyarakat, terutama masyarakat kecil yang tidak bankable dan menolak riba, karena berorientasi pada ekonomi kerakyatan. Kehadiran BMT di satu sisi menjalankan misi ekonomi syariah dan di sisi lain mengemban tugas ekonomi kerakyatan dengan meningkatkan ekonomi mikro, itulah sebabnya perkembangan BMT sangat pesat di tengah perkembangan lembaga keuangan mkro konvensional lainnya.

Namun, perkembangan BMT ini tidak diikuti dengan pengaturan dan landasan hukum yang jelas. BMT memiliki karakteristik yang khas jika dibandingkan dengan lembaga keuangan lain yang ada, karena selain memiliki misi komersial (Baitut Tamwil) juga memiliki misi sosial (Baitul Maal), oleh karenanya BMT bisa dikatakan sebagai jenis lembaga keuangan mikro baru dari yang telah ada sebelumnya. Beberapa BMT mengambil bentuk hukum koperasi, namun hal ini masih bersifat pilihan, bukan keharusan. BMT dapat 
didirikan dalam bentuk Kelompok Swadaya Masyarakat (KSM) ataupun dapat juga berbentuk badan hukum koperasi. Sebelum menjalankan usahanya, KSM harus mendapatkan sertifikat dari PINBUK ${ }^{2}$ dan PINBUK harus mendapatkan pengakuan dari Bank Indonesia sebagai Lembaga Pengembang Swadaya Masyarakat (LPSM) yang mendukung Program Proyek Hubungan Bank dengan Kelompok Swadaya Masyarakat yang dikelola oleh Bank Indonesia (PHBK-BI).

Sejak awal kelahirannya sampai dengan saat ini, legalitas BMT belum ada, hanya saja banyak BMT memilih badan hukum koperasi. Oleh karena itu BMT tunduk pada aturan perkoperasian, yaitu Undang-Undang No.25 Tahun 1992 tentang Koperasi yang telah diubah menjadi Undang-Undang No 17 Tahun 2012 tentang Koperasi. KEPMEN Nomor 91/KEP/M.KUKM/IX/2004 tentang Petunjuk Pelaksanaan Kegiatan Usaha Koperasi Jasa Keuangan Syariah (KJKS). Aturan hukum tersebut selanjutnya dijabarkan dalam Petunjuk Pelaksanaan (JUKLAK) dan Petunjuk Teknis (JUKNIS) serta Standar Operasional Prosedur (SOP) dan Standar Operasional Menejemen (SOM) yang tunduk pada PERMEN Nomor 352/PER/M.KUKM/X/2007 tentang Pedoman standar Operasional Manajemen Koperasi Jasa Keuangan Syariah dan Unit Usaha Jasa Keuangan Syariah.

Namun, sejak adanya Undang-Undang No 1 Tahun 2013 tentang Lembaga Keuangan Mikro (LKM), status kelembagaan badan hukum BMT menjadi suatu permasalahan tersendiri yang membebani BMT. BMT yang sudah ada saat ini kebanyakan adalah berbadan hukum koperasi dengan skala usaha kecil menengah dan cakupan luas usaha meliputi beberpa kota/kabupaten, bahkan lintas propinsi. Namun, dengan pengaturan BMT

\footnotetext{
2 PINBUK adalah Pusat Inkubasi Bisnis Usaha Kecil atau Center for Mikro Enterprise Incubation yang didirikan pada tanggal 13 Maret 1995 di Jakarta oleh Prof. Dr. B.J. Habibie Ketua Umum ICMI (Ikatan Cendekiawan Muslim se Indonesia), K.H. Hasan Basri (Ketua Umum MUI) dan Zainul Bahar Noor (Direktur Utama Bank Muammalat Indonesia). PINBUK didirikan dengan mengembangkan model Lembaga Keuangan Mikro-Baitul Maal wa Tamwil (LKM-BMT) sebagai strategi pemberdayaan masyarakat melalui penumbuhkembangan keswadayaan dan kelembagaan sosial ekonomi yang dapat menjangkau dan melayani lebih banyak unit usaha mereka yang tidak mungkin dijangkau langsung oleh perbankan umum. Sejarah dan Latar Belakang Kelabiran BMT, (Inkopsyah, 2010).
} 
Analisis Normatif Undang-undang No. 1 Taun 2013

sebagai LKM ${ }^{3}$ sebagaimana dalam UU No. 1 Tahun 2013, keluasan cakupan usaha BMT menjadi dibatasi. ${ }^{4}$ Bila ingin melebarkan usahanya ke kota/kabupaten lain, maka BMT harus bertransformasi menjadi bank. ${ }^{5}$ Dengan demikian, maka yang memiliki kewenangan atas pengawasan berubah dari Kementrian Koperasi dan Usaha Kecil dan Menengah menjadi Otoritas Jasa Keuangan. ${ }^{6}$ Perubahan pengawasan ini menjadi kekhawatiran tersendiri bagi BMT, sekaligus menjadi celah hukum, bila pengawasan BMT masih tetap berada di bawah pengawasan Kementrian Koperasi dan UKM.

\section{Permasalahan}

Berdasarkan realitas yang sudah dipaparkan di atas inilah, penulis akan mengkaji lebih dalam menggunakan optik rechtdogmatiek empiric dalam tulisan yang berjudul "Analisi Sosio Legal Undang-Undang No. 1 Tahun 2013 tentang Lembaga Keuangan Mikro (LKM) Atas Status Badan Hukum dan Pengawasan Baitul Maal Wat Tamwil (BMT)". Permasalahan yang diangkat dalam tulisan ini adalah bagaimana status badan hukum dan pengawasan BMT sebelum dan sesudah adanya Undang-Undang No. 1 Tahun 2013 tentang Lembaga Keuangan Mikro?

${ }^{3}$ Lembaga Keuangan Mikro yang selanjutnya disingkat LKM adalah lembaga keuangan yang khusus didirikan untuk memberikan jasa pengembangan usaha dan pemberdayaan masyarakat, baik melalui pinjaman atau pembiayaan dalam usaha skala mikro kepada anggota dan masyarakat, pengelolaan simpanan, maupun pemberian jasa konsultasi pengembangan usaha yang tidak sematamata mencari keuntungan. Pasal 1 ayat (1) Undang-Undang No. 1 Tahun 2013 tentang Lembaga Keuangan Mikro.

4 Pasal 16 Ayat (1) Undang-Undang No. 1 Tahun 2013 tentang Lembaga Keuangan Mikro menyatakan bahwa, "cakupan wilayah usaha suatu LKM berada dalam satu wilayah desa/ kelurahan, kecamatan, atau kabupaten/kota.

${ }^{5}$ Pasal 27 Undang-Undang No/ 1 Tahun 2013 tentang Lembaga Keuangan Mikro, bahwa "LKM wajib bertransformasi menjadi bank jika: a. LKM melakukan kegiatan usaha melebihi 1 (satu) wilayah kabupaten/kota tempat kedudukan LKM; atau b. LKM telah memenuhi persyaratan yang ditetapkan dalam Peraturan Otoritas Jasa Keuangan”.

'Otoritas Jasa Keuangan adalah Otoritas Jasa Keuangan sebagaimana dimaksud dalam Undang-Undang tentang Otoritas Jasa Keuangan, Pasal 1 ayat (8) Undang-Undang No. 1 Tahun 2013 tentang Lembaga Keuangan Mikro (LKM). Otoritas Jasa Keuangan, yang selanjutnya disingkat OJK, adalah lembaga yang independen dan bebas dari campur tangan pihak lain, yang mempunyai fungsi, tugas, dan wewenang pengaturan, pengawasan, pemeriksaan, dan penyidikan sebagaimana dimaksud dalam Undang- Undang ini. Pasal 1 Ayat (1) Undang-Undang No. 11 Tahun 2011 tentang Otoritas Jasa Keuangan (OJK). 


\section{Pembahasan}

Baitul Maal Wat Tammil adalah salah satu lembaga keuangan mikro ${ }^{7}$ yang memiliki angka pertumbuhan sangat pesat dari tahun ke tahun, sebagaimana disampaikan oleh Joelarso, Ketua Umum Dewan Pimpinan Pusat Perhimpunan BMT Indonesia, "hingga akhir 2012 ini, terdapat 3.900 BMT. Sebanyak 206 di antaranya bergabung dalam asosiasi BMT seluruh Indonesia. Pada tahun 2005, seluruh aset 96 BMT yang menjadi anggota asosiasi mencapai Rp 364 miliar. Pada 2006, aset tumbuh menjadi Rp 458 miliar, dan hingga akhir 2011 jumlah aset mencapai Rp 3,6 triliun dari 206 BMT yang bergabung di asosiasi". ${ }^{8}$ Dalam perkembangannya, di tahun 2013, angka pertumbuhan BMT sudah mencapai lebih dari 5500 BMT yang tersebar di seluruh Indonesia. ${ }^{9}$ Sebagai bagian dari LKM yang terus bertumbuh ${ }^{10}$, sebagaimana data yang disampaikan oleh Kepala Eksekutif Pengawas Industri Keuangan Non Bank Otoritas Jasa Keuangan Firdaus Djaelani, yang memperkirakan bahwa saat ini jumlah LKM di Indonesia sekitar 567 ribu sampai 600 ribu unit. ${ }^{11}$ Ini menunjukkan bahwa lembaga keuangan mikro adalah lembaga keuangan yang sangat dibutuhkan oleh masyarakat kecil, khususnya di daerah-daerah untuk menunjang dan mendukung pertumbuhan ekonomi kerakyatan, terutama masyarakat berpenghasilan rendah yang selama ini tidak terjangkau oleh layanan perbankan.

7 Pasal 39 Undang-Undang No. 1 Tahun 2013 tentang Lembaga Keuangan Mikro, "pada saat Undang-Undang ini mulai berlaku, Bank Desa, Lumbung Desa, Bank Pasar, Bank Pegawai, Badan Kredit Desa (BKD), Badan Kredit Kecamatan (BKK), Kredit Usaha Rakyat Kecil (KURK), Lembaga Perkreditan Kecamatan (LPK), Bank Karya Produksi Desa (BKPD), Badan Usaha Kredit Pedesaan (BUKP), Baitul Maal wa Tamwil (BMT), Baitul Tamwil Muhammadiyah (BTM), dan/atau lembagalembaga lainnya yang dipersamakan dengan itu tetap dapat beroperasi sampai dengan 1 (satu) tahun terhitung sejak Undang-Undang ini berlaku”.

${ }^{8}$ Joelarso, BMT Summit 2012, Yogyakarta, Universitas Gajah Mada, 7 November 2012.

9 Muhammad Zubair Mughal, CEO Al Huda Center of Islamic Banking and Economics, internasional Conference "Empowering SMEs for Financial Inclusion and Growth", (Jakarta: 2014)

${ }^{10}$ Data tentang BMT yang ada di Indonesia ini hanya dapat diinventaris dari data Asosiasi BMT Indonesia, di mana BMT-BMT yang tergabung dan dapat didata oleh asosiasi hanyalah BMT yang menjadi anggota asosiasi, sedangkan di luar keanggotaan, masih banyak tersebar BMT. Dengan demikian data mengenai jumlah valid seluruh BMT yang ada di Indonesia tidak ada yang mengetahuinya, begitu juga dengan Kementrian Koperasi dan UKM sekalipun tidak memiliki data BMT yang merupakan Koperasi Jasa Keuangan Syariah.

${ }^{11}$ Majalah Warta Ekonomi Edisi No. 08/XXV/2013 
Analisis Normatif Undang-undang No. 1 Taun 2013

Di Jawa Tengah sendiri, data tentang BMT yang berbadan hukum Koperasi Jasa Keuangan Syariah (KJKS) juga tidak ada, karena data itu tergabung dalam keseluruhan data koperasi, bahwa pada semester pertama tahun 2014, jumlah koperasi adalah 27.572 unit. Koperasi yang dinyatakan aktif adalah sebanyak 22.279 unit $(80,80 \%$ ) dan yang tidak aktif sebanyak 5.293 unit $(19,20 \%)$ dengan total keanggotaan koperasi adalah 6.878 .580 orang dengan tenaga kerja berjumlah 122.318 orang. Aset koperasi di Jawa tengah sampai dengan tahun 2014 adalah Rp. 37,378 Trilyun dengan omset sebesar Rp. 27,863 Trilyun. ${ }^{12}$

\section{Grafik Perkembangan Jumlah Koperasi}

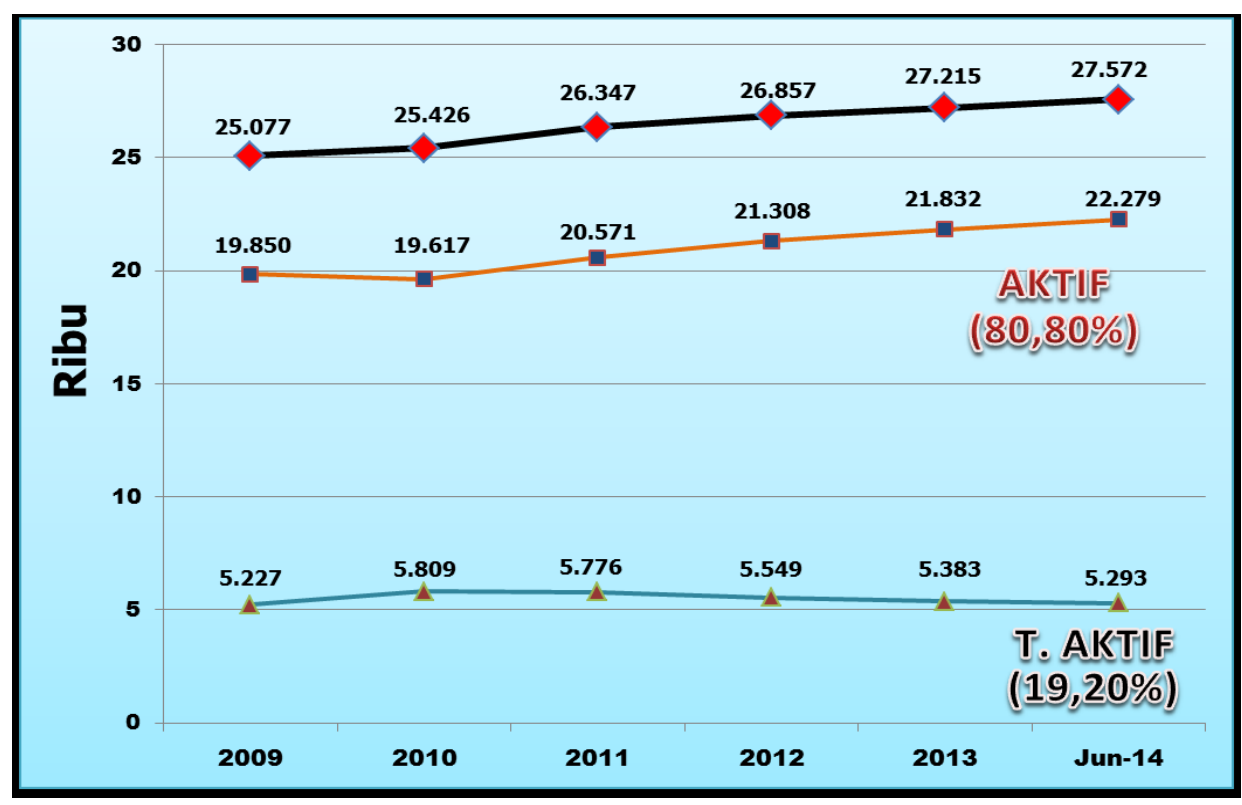

Sumber: Dinas Koperasi Jawa Tengah Tahun 2014

${ }^{12}$ Laporan Pembangun Sektor dan UMKM Dinas Koperasi Jawa Tengah Semester I Tahun 


\section{Grafik Perkembangan Anggota Koperasi}

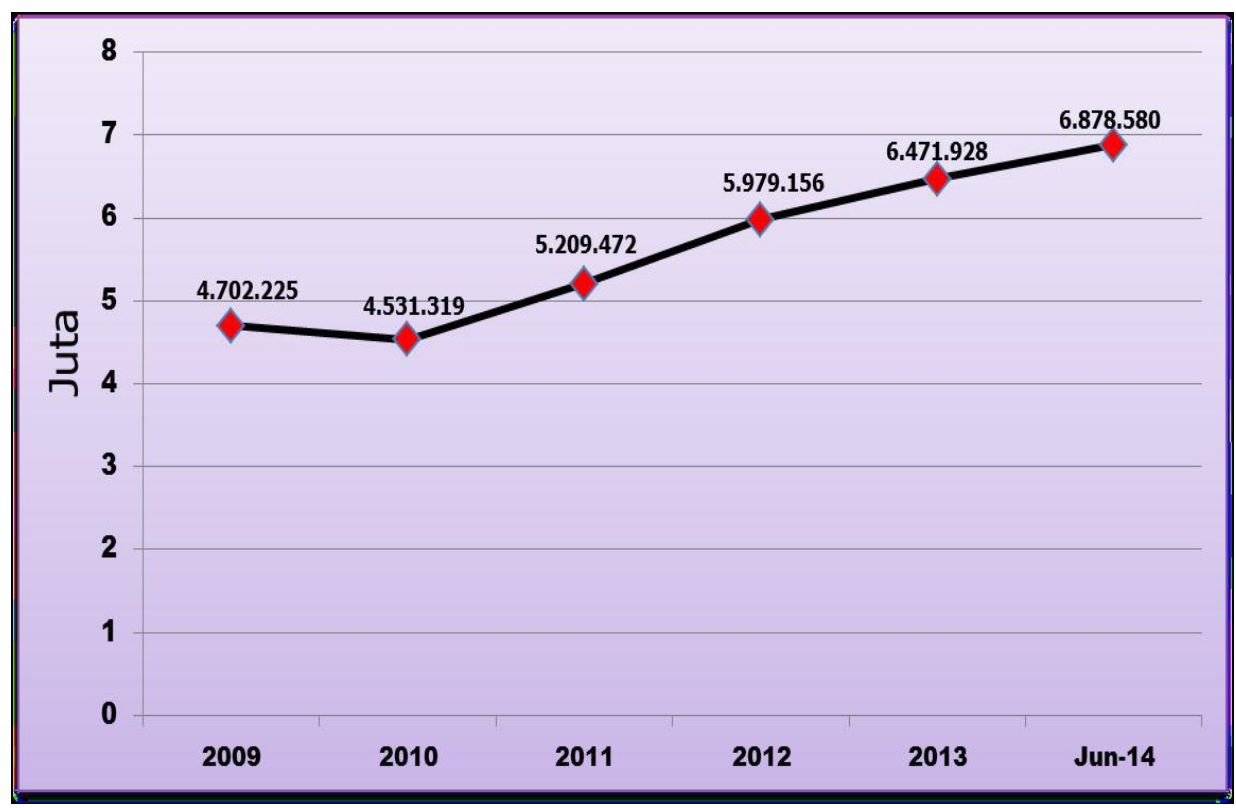

Sumber: Dinas Koperasi Jawa Tengah Tahun 2014

Grafik Perkembangan Omset dan Aset Koperasi

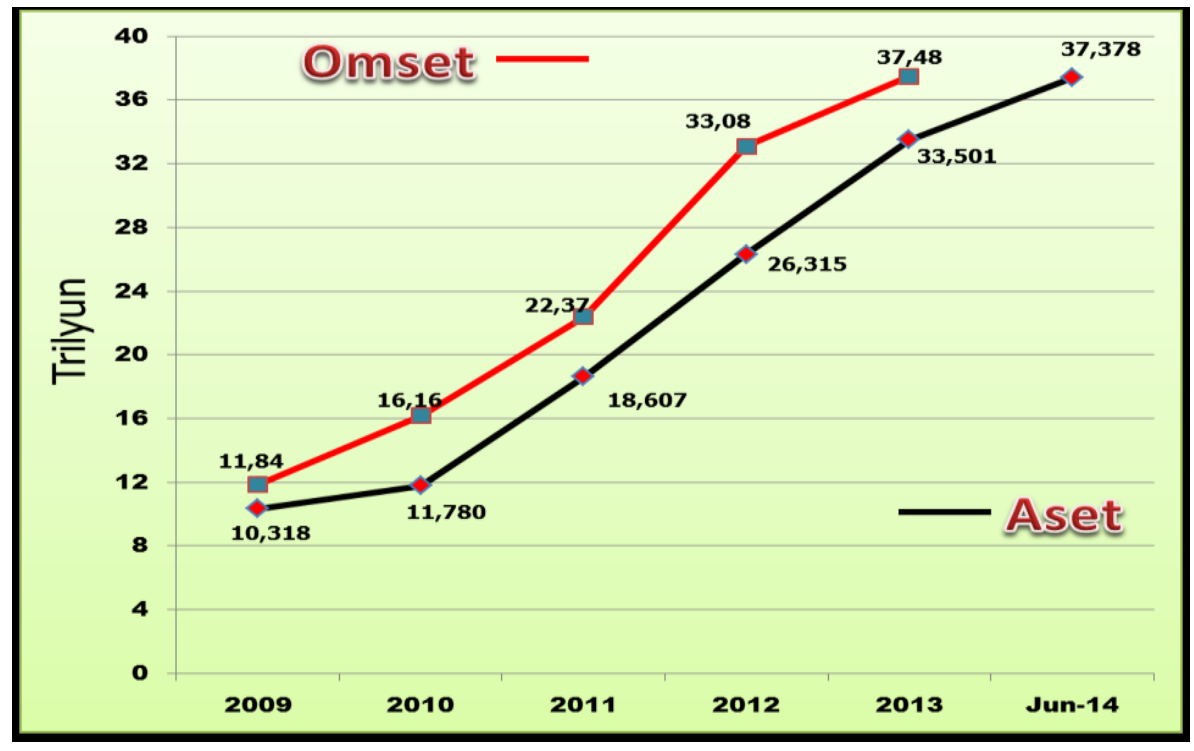

Sumber: Dinas Koperasi Jawa Tengah Tahun 2014 
Analisis Normatif Undang-undang No. 1 Taun 2013

Sedangkan untuk data Koperasi Simpan Pinjam sebagai lembaga keuangan mikro dapat berbentuk KSP (Koperasi Simpan Pinjam), USP (Unit Simpan Pinjam), KJKS (Koperasi Jasa Keuangan Syariah) dan UJKS (Unit Jasa Keuangan Syariah) di tahun 2014 adalah :13

- Jumlah KSP/USP/KJKS/UJKS : 22.079 unit

- Anggota KSP/USP/KJKS/UJKS : 5.649 .609 orang

- Tenaga Kerja : 69.569 orang

- Total Modal : Rp. 29,120 triliun

- Volume Usaha : Rp. 25,796 triliun

- Sisa Hasil Usaha : Rp. 359,314 milyar

Hingga Juni 2014, Kondisi kesehatan KSP/USP/KJK/KJKS di Jawa Tengah adalah sebagai berikut: ${ }^{14}$

- Predikat Sehat

- Predikat Cukup Sehat

- Predikat Kurang Sehat

- Predikat Tidak Sehat

- Predikat Sangat Tidak Sehat

- Tidak Dapat Dinilai

$$
\begin{aligned}
& : 2.027 \mathrm{KJK}(15,54 \%) \\
& : 7.598 \mathrm{KJK}(58,24 \%) \\
& : 216 \mathrm{KJK}(1,66 \%) \\
& : 11 \mathrm{KJK}(0,08 \%) \\
& : 2 \mathrm{KJK}(0,02 \%) \\
& : 3.193 \mathrm{KJK}(24,47 \%)
\end{aligned}
$$

Sedangkan untuk KSP/USP/KJK/KJKS Tingkat Provinsi dari jumlah 437, per Juni 2014 telah dilakukan penilaian kesehatan bagi 112 KSP/USP/KJK/KJKS dengan hasil sebagai berikut : 15

- Predikat Sehat

- Predikat Cukup Sehat

- Predikat Kurang Sehat

Namun perkembangan Koperasi Jasa Keuangan Syariah (KJKS) ini sangat ironis karena seiring pertumbuhan BMT yang semakin pesat mengikuti perkembangan kebutuhan masyarakat, eksistensi BMT tidak ditunjang dengan

${ }^{13}$ Laporan Pembangun Sektor dan UMKM Dinas Koperasi Jawa Tengah Semester I Tahun 2014

$$
\begin{aligned}
& { }^{14} \text { Ibid. } \\
& { }^{15} \text { Ibid. }
\end{aligned}
$$


regulasi yang dapat memberikan perlindungan hukum yang kuat terhadap eksistensi kelembagaan BMT. Dari awal keberadaan BMT sampai dengan saat ini tunduk pada beberapa peraturan perundang-undangan. Hal ini disebabkan karakteristik BMT berbeda dengan lembaga keuangan mikro lainnya. BMT memiliki fungsi sosial sekaligus profit sebagai lembaga keuangan, sehingga membutuhkan aturan yang bersifat spesifik sesuai dengan karakteristik yang dimiliki BMT. Sebagaimana disampaikan oleh Rahmat Riyadi dari Dompet Dhuafa yang selama ini telah membina 155 BMT, bahwa 'kendala yang dihadapi BMT dari aspek hukum adalah regulasi yang belum lengkap. Menurutnya karena BMT bergerak di wilayah yang tidak dibatasi dengan sistem yang ketat, dan bergerak dalam sektor nonformal sepeti koperasi, maka perkembangan lembaga ini lebih pesat tetapi untuk jangka panjang harus disistematisir. ${ }^{16}$

BMT dikepung oleh beberapa peraturan yang menaunginya, sesuai dengan bentuk badan hukum BMT itu sendiri. Sampai saat ini BMT ada yang telah berbadan hukum dan ada pula yang belum berbadan hukum. BMT yang berbadan hukum, pada umumnya menggunakan badan hukum yayasan dan koperasi. Sedangkan BMT yang belum berbadan hukum pada umumnya menggunakan KSM (Kelompok Swadaya Masyarakat). Dan ada beberapa BMT yang tidak diketahui bentuk hukumnya. ${ }^{17}$

\section{Status Badan Hukum dan Pengawasan BMT Sebelum Undang- undang No. 1 Tahun 2013 tentang Lembaga Keuangan Mikro}

BMT yang berstatus badan hukum koperasi, tunduk pada peraturan perundang-undangan :

16 Rahmat Riyadi, Konsep dan Stategi pemberdayaan LKMS di Indonesia, makalah disampaikan pada Seminar Nasional Kontribusi Hukum dalam Pemberdayaan LKMS, Fakultas Hukum Undip, Semarang, 18 Desember 2007.hal. 8.

${ }^{17}$ Neni Sri Imaniyati, Aspek-Aspek Hukum BMT, Bandung, Citra Adtya Bakti, 2010), hlm. 99101

Volume V/Edisi 2/Oktober 2014 
Analisis Normatif Undang-undang No. 1 Taun 2013

1. Undang-Undang No. 25 Tahun 1992 tentang Koperasi yang telah diubah menjadi Undang-Undang No. 17 Tahun Tahun 2012 tentang Perkoperasian,

2. Peraturan Pemerintah RI No. 9 Tahun 1995 Tentang Pelaksanaan Kegiatan Usaha Simpan Pinjam oleh koperasi ${ }^{18}$,

3. Keputusan Menteri Negara Koperasi dan Usaha Kecil dan Menengah Nomor 91/Kep/M. KUKM/IX/2004 tentang Petunjuk Pelaksanaan Kegiatan Usaha Koperasi Jasa Keuangan Syari'ah,

a. Secara teknis mengenai penerapan akad mudharabah dalam bentuk pembiayaan diatur dalam Fatwa DSN MUI No. 07/DSNMUI/IV/2000 tentang Pembiayaan Mudharabah (Qiradh)

b. Secara teknis mengenai penerapan akad musyarakah dalam produk pembiayaan diatur dalam Fatwa DSN MUI No. 08/DSNMUI/IV/2000 tentang Pembiayaan Musyarakah.

c. Secara teknis mengenai implementasi akad murabahah diatur dalam Fatwa DSN MUI No. 04/DSN-MUI/IV/2000 tentang Murabahah,

d. Secara teknis mengenai implementasi akad salam, tunduk pada Fatwa DSN MUI No. 05/DSN-MUI/IV/2000 tentang Jual Beli Salam,

e. Secara teknis mengenai implementasi akad istishna, tunduk pada Fatwa DSN MUI No. 06/DSN-MUI/IV/2000 tentang Jual Beli Istishna.

f. Secara teknis mengenai penerapan akad ijarah tunduk pada Fatwa DSN MUI No. 09/DSN-MUI/IV/2000 tentang Pembiayaan Ijarah.

g. Secara teknis mengenai implementasi Ijarah Muntabia Bit Tamlik (IMBT) ini tunduk pada ketentuan Fatwa DSN MUI No. 27/DSNMUI/III/2002 tentang Al-Ijarah Al-Mutahiyah bi Al-Tamlik.

h. Secara teknis mengenai pembiayaan qardh ini tunduk pada Fatwa DSN MUI No. 19/DSN-MUI/IX/2000 tentang al Qardh.

4. Peraturan Menteri Negara Koperasi dan Usaha Kecil dan Menengah 35.2/Per/M.KUKM/X/2007 tentang Pedoman Standar Operasional Manajemen Koperasi Jasa Keuangan Syari'ah, dan

18 Undang-Undang No. 17 Tahun 2012 tentang Perkoperasian telah dibatalkan oleh Mahkamah Konstitusi pada tanggal 28 Mei 2014 pukul 09.30 WIB oleh Ketua Majelis Hakim sekaligus Ketua Mahkamah Konstitusi Hamdan Zoelva, sehingga sebagai konsekuensi logis kembali pada Undang-Undang No. 25 Tahun 1992 tentang Koperasi. 
5. Peraturan Menteri Negara Koperasi dan Usaha Kecil dan Menengah 39/Per/M.KUKM/XII/2007 tentang Pedoman Pengawasan Koperasi Jasa Keuangan Syari'ah dan Unit Jasa Keuangan Syariah Koperasi,

Apabila dianalisis lebih mendalam, eksistensi kelembagaan atas status badan hukum BMT sebagai Koperasi Jasa Keuangan Syariah (KJKS) yang tunduk kepada UU No. 25 Tahun 1992 tentang Perkoperasian dan telah diubah menjadi Undang-Undang No. 17 Tahun 2012 tentang Perkoperasian yang selanjutnya telah dibatalkan oleh Mahkamah Konstitusi dan kembali pada undang-undang yang lama yaitu Undang-Undang No. 25 Tahun 1992 tentang Perkoperasian, masih belum mampu mengakomodir keberadaan BMT sebagai salah satu lembaga keuangan yang melayani kebutuhan masyarakat. Hal ini disebabkan, BMT berbeda dengan koperasi jenis koperasi pada umumnya ${ }^{19}$, karena BMT dilaksanakan dengan prinsip syariah yang berbeda dengan koperasi konvensional dan dalam BMT terdapat misi sosial sebagai Baitul Maal yang tidak bisa dipaksakan tunduk sepenuhnya pada undang-undang koperasi.

Eksistensi kelembagaan BMT sebenarnya telah diakomodir dengan adanya undang-undang koperasi yang baru, yaitu Undang-Undang No. 17 Tahun 2012 tentang Perkoperasian, di mana dalam undang-undang ini disebutkan adanya pengelolaan koperasi dengan menggunakan prinsip syariah, sebagaimana diatur dalam Pasal 87 Ayat (3), bahwa "Koperasi dapat menjalankan usaha atas dasar prinsip ekonomi syariah", selanjutnya dalam Pasal 87 Ayat (4), bahwa "Ketentuan mengenai Koperasi berdasarkan prinsip ekonomi syariah sebagaimana dimaksud pada ayat (3) diatur dengan Peraturan Pemerintah". Peraturan pemerintah yang selanjutnya mengatur BMT adalah Keputusan Menteri Negara Koperasi dan Usaha Kecil dan Menengah Nomor 91/Kep/M. KUKM/IX/2004 tentang Petunjuk Pelaksanaan Kegiatan Usaha Koperasi Jasa Keuangan Syari'ah, Peraturan Menteri Negara Koperasi dan Usaha Kecil dan Menengah 35.2/Per/M.KUKM/X/2007 tentang Pedoman Standar Operasional Manajemen Koperasi Jasa Keuangan Syari'ah, dan

${ }^{19}$ Jenis-jenis koperasi menurut Undang-Undang No. 25 Tahun 1992 tentang Perkoperasian adalah Koperasi Simpan Pinjam (KSP), Koperasi Serba Usaha (KSU), Koperasi Produksi dan Koperasi Konsumsi. Namun selanjutnya, dalam undang-undang koperasi yang baru, yaitu UndangUndang No. 17 tahun 2012 tentang Perkoperasian (yang telah dibatalkan oleh Mahkamah Konstitusi) tidak lagi menyebutkan Koperasi Serba Usaha, dan menyatakan bahwa jenis-jenis koperasi adalah: Koperasi Konsumen, Koperasi Produsen, Kperasi Jasa dan Koperasi Simpan Pinjam. 
Analisis Normatif Undang-undang No. 1 Taun 2013

Peraturan Menteri Negara Koperasi dan Usaha Kecil dan Menengah 39/Per/M.KUKM/XII/2007 tentang Pedoman Pengawasan Koperasi Jasa Keuangan Syari'ah dan Unit Jasa Keuangan Syariah Koperasi.

Namun dengan dibatalkannya Undang-Undang No. 17 Tahun 2012 tentang Perkoperasian ${ }^{20}$, pengaturan tentang koperasi yang berlandaskan prinsip syariah dihapuskan dan kembali pada Undang-Undang No. 25 Tahun 1992 tentang Perkoperasian yang sama sekali tidak mengatur tentang koperasi yang berlandaskan prinsip syariah. Namun, menurut Direktur Koperasi Jasa Keuangan Syariah Baitut Tamwil Tamzis Wonosobo, bahwa "sekarang kami tidak lagi mempunyai aturan setara undang-undang yang bisa mengatur keberadaan BMT, karena Undang-Undang No. 17 Tahun 2012 tentang Perkoperasian yang secara spesifik telah mengatur penggunaan prinsip syariah dalam pelaksanaan koperasi telah dibatalkan dan kembali pada undang-undang lama yang belum mengikuti perkembangan kebutuhan masyarakat dan tidak belum mengakomodir spesifikasi BMT sebagai koperasi dengan prinsip syariah". ${ }^{21}$

Pengawasan dalam BMT yang berbadan hukum Koperasi Jasa Keuangan Syariah (KJKS) tunduk pada Peraturan Menteri Koperasi dan UKM Nomor 39/Per/M.KUKM/XII/2007 tentang Pedoman Pengawasan Koperasi Jasa Keuangan Syariah dan Unit Jasa Keuangan Syariah Koperasi. Pengawasan BMT yang berbadan hukum koperasi dilakukan oleh Kementrian Koperasi dan UKM di mana domisili BMT berada, apabila di tingkat kota dilakukan

20 Permohonan Judicial Review atas Undang-Undang No. 17 Tahun 2012 tentang Perkoperasian diajukan oleh Pemohon: Yayasan Bina Desa Sadajiwa, dalam hal ini diwakili oleh Dwi Astuti, sebagai Pemohon I; Koperasi Karya Insani, dalam hal ini diwakili oleh Yuyu Rahayu, sebagai Pemohon II; Yayasan Pemberdayaan Perempuan Kepala Keluarga, dalam hal ini diwakili oleh Ir. Zulminarni, disebut sebagai Pemohon III; Asosiasi Pendamping Perempuan Usaha Kecil (ASPPUK), dalam hal ini diwakili oleh Endang Susilowati, disebut sebagai Pemohon IV; Asosiasi Pusat Pengembangan Sumberdaya Wanita (PPSW), dalam hal ini diwakili oleh Ir. Kodar Tri Wusaningsih, MS., disebut sebagai Pemohon V; Lembaga Pengkajian dan Pengembangan Koperasi (LePPek), dalam hal ini diwakilih oleh Suroto dan Sukma Fitri Astuti, disebut sebagai Pemohon VI; Wigatiningsih, disebut sebagai Pemohon VII; Sri Agustin Trisnantari, disebut sebagai Pemohon VIII; Sabiq Mubarok, disebut sebagai Pemohon IX; Maya Saphira, S.E., disebut sebagai Pemohon X; Chaerul Umam, disebut sebagai Pemohon XI.

${ }^{21}$ Wawancara dengan Budi Santoso, S.E., Direktur Koperasi Jasa Keuangan Syariah Baitut Tamwil Tamzis Wonosobo, pada hari Rabu, tanggal 28 Agustus 2014, di Kantor Pusat KJKS Baitut Tamwil Tamzis Wonosobo. 
oleh Dinas Koperasi dan UKM Kota/Kabupaten, sedangkan bila di tingkat provinsi, maka dilakukan oleh Dinas Koperasi dan UKM Provinsi.

\section{Status Badan Hukum dan Pengawasan BMT Sebelum undang- Undang No. 1 Tahun 2013 tentang Lembaga Keuangan Mikro}

BMT dapat dikelompokkan menjadi 3 kelompok, bila dilihat dari status badan hukumnya, yaitu:

1. BMT yang berbadan hukum koperasi dalam bentuk Koperasi Jasa Keuangan Syariah dan tunduk pada Undang-Undang No. 25 Tahun 1992 tentang Perkoperasian, yang selanjutnya dalam kegiatan usahanya tunduk pada :

a. Keputusan Menteri Negara Koperasi dan Usaha Kecil dan Menengah Nomor 91/Kep/M. KUKM/IX/2004 tentang Petunjuk Pelaksanaan Kegiatan Usaha Koperasi Jasa Keuangan Syari'ah,

b. Peraturan Menteri Negara Koperasi dan Usaha Kecil dan Menengah 35.2/Per/M.KUKM/X/2007 tentang Pedoman Standar Operasional Manajemen Koperasi Jasa Keuangan Syari'ah, dan

c. Peraturan Menteri Negara Koperasi dan Usaha Kecil dan Menengah 39/Per/M.KUKM/XII/2007 tentang Pedoman Pengawasan

Koperasi Jasa Keuangan Syari'ah dan Unit Jasa Keuangan Syariah Koperasi,

2. BMT sebagai badan usaha milik yayasan dan tunduk pada UndangUndang No. 25 Tahun 1992 tentang Koperasi sekaligus pada UndangUndang No. 28 Tahun 2004 tentang Perubahan Atas Undang-Undang No. 16 Tahun 2001 tentang Yayasan.

3. BMT yang masih berbentuk Kelompok Swadaya Masyarakat (KSM) dan tunduk pada Undang-Undang No. 17 Tahun 2013 tentang Organisasi Masyarakat.

Apabila dilihat dari ketiga kelompok karakteristik BMT berdasarkan status badan hukumnya tersebut, maka dengan diberlakukannya UndangUndang No. 1 Tahun 2013 tentang Lembaga Keuangan Mikro, BMT dapat 
Analisis Normatif Undang-undang No. 1 Taun 2013

dikatakan sebagai salah satu lembaga keuangan mikro bila memiliki status badan hukum koperasi, sebagaimana dinyatakan dalam UU No. 1 Tahun 2013 tentang Lembaga Keuangan Mikro, bahwa pendirian LKM paling sedikit harus memeilikin persyaratan :22

a. Bentuk badan hukum

b. Permodalan; dan mendapatkan izin usaha ${ }^{23}$ yang tata caranya diatur dalam undang-undang ini.

Bentuk badan hukum yang dimaksud adalah koperasi atau Perseroan Terbatas. ${ }^{24}$ Apabila lembaga keuangan tersebut berbadan hukum koperasi, maka akan tunduk pada Undang-Undang No. 25 Tahun 1992 tentang Perkoperasian. Sedangkan apabila lembaga keuangan tersebut berbadan hukum Perseroan Terbatas, maka tunduk pada Undang-Undang No. 40 Tahun 2007 tentang Perseroan Terbatas. Lembaga Keuangan Mikro wajib bertransformasi menjadi bank jika LKM melakukan kegiatan usaha melebihi 1 (satu) wilayah Kabupaten/Kota tempat kedudukan LKM dan telah memenuhi persyaratan yangditetapkan dalam Peraturan Jasa Keuangan Syariah. ${ }^{25}$

Jika melihat pengaturan dari Pasal 27 Undang-Undang No 1 Tahun 2013 tentang Lembaga Keuangan Mikro ini bisa terjadi keambiguan dalam penafsirannya, karena dalam Pasal 5 Undang-Undang No 1 Tahun 2013 tentang Lembaga Keuangan Mikro hanya disebutkan bahwa LKM memiliki bentuk badan hukum koperasi atau Perseroa Terbatas (PT), sedangkan semua bank memiliki status badan hukum Perseroan Terbatas dan tunduk pada Undang-Undang No. 40 Tahun 2007 tentang Perseroan Terbatas. Dengan demikian akan muncul pertanyaan, "apakah dengan demikian, yang dimaksud untuk bertransformasi menjadi bank adalah LKM dalam bentuk koperasi apabila melakukan kegiatan usaha melebihi 1 (satu) wilayah Kabupaten/Kota tempat kedudukan LKM?" Pertanyaan selanjutnya, "apabila demikian, apakah LKM dalam bentuk koperasi hanya boleh melakukan kegiatan usaha di 1 (satu)

\footnotetext{
22 Pasal 4 Undang-Undang No 1 Tahun 2013 tentang Lembaga Keuangan Mikro.

23 Izin usaha yang dimaksud adalah dari Otoritas Jasa Keuangan (OJK) dengan persyaratanpersyaratan: (a) susunan organisasi dan kepengurusan, permodalan, kepemilikan; dan kelayakan rencana kerja. Pasal 9 Ayat (1) dan (2) Undang-Undang No 1 Tahun 2013 tentang Lembaga Keuangan Mikro.

${ }^{24}$ Pasal 5 Ayat (1) Undang-Undang No 1 Tahun 2013 tentang Lembaga Keuangan Mikro.

${ }^{25}$ Pasal 27 Undang-Undang No 1 Tahun 2013 tentang Lembaga Keuangan Mikro
} 
wilayah Kabupaten/Kota saja? apabila melebihi satu Kota/Kabupaten harus berubah menjadi bank dan merubah status badan hukumnya menjadi perseroan terbatas?

Pertanyaan-pertanyaan tersebut di atas akan sangat berhubungan dengan permasalahan pengawasan LKM pasca Undang-Undang No. 1 Tahun 2013 tentang Lembaga Keuangan Mikro diundangan dan mulai diberlakukan. ${ }^{26}$ Karena menurut Undang-Undang No. 1 Tahun 2013 tentang Lembaga Keuangan Mikro dijelaskan bahwa bentuk badan hukum LKM sangat mempengaruhi pengawasannya, khusunya lembaga yang akan mengawasinya. Sebagaimana dinyatakan dalam Pasal 28 Ayat (1), (2), Undang-Undang No. 1 Tahun 2013 tentang Lembaga Keuangan Mikro, bahwa :

(1) Pembinaan, pengaturan dan pengawasan LKM dilakukan oleh Otoritas Jasa Keuangan ${ }^{27}$;

(2) Dalam melakukan pembinaan sebagaimana dimaksud pada Ayat (1) Otoritas Jasa Keuang melakukan koordinasi dengan kementrian yang menyelenggarakan urusan koperasi dan Kementrian Dalam Negeri.

Berdasarkan pasal tersebut berarti pengawasan LKM berada di tiga kementrian, yaitu Otoritas Jasa Keuangan (OJK), Kementrian Koperasi dan UKM dan Kementrian Dalam Negeri28, sebagaimana nota kesepahaman yang telah ditandatangani oleh tiga kementrian, yaitu oleh Ketua Dewan Komisioner Otoritas Jasa Keuangan (OJK) Muliaman D. Hadad, Menteri Dalam Negeri, Gamawan Fauzi dan Menteri Koperasi dan UKM, Sjarifudin

${ }^{26}$ Peraturan Pelaksanaan dari undang-undang ini harus ditetapkan paling lama 2 (dua) tahun terhitung sejak undang-undang ini diundangkan dan undang-undang ini mulai berlaku setelah 2 (dua) tahun terhitung sejak tanggal diundangkan. Pasal 41 dan 42 Undang-Undang No 1 Tahun 2013 tentang Lembaga Keuangan Mikro.

27 Otoritas Jasa Keuangan, yang selanjutnya disingkat OJK, adalah lembaga yang independen dan bebas dari campur tangan pihak lain, yang mempunyai fungsi, tugas, dan wewenang pengaturan, pengawasan, pemeriksaan, dan penyidikan sebagaimana dimaksud dalam Undang-Undang ini. Pasal 1 Angka 1 Undang-Undang No. 21 Tahun 2011 tentang Otoritas Jasa Keuangan.

${ }_{28}$ Sebagaimana diamanatkan oleh Pasal 40 Ayat (1) Undang-Undang No. 1 Tahun 2013 tentang Lembaga Keuangan Mikro, bahwa :"Otoritas Jasa Keuangan, Kementrian yang menyelenggarakan urusan koperasi dan Kementrian Dalam Negeri harus melakukan inventarisasi LKM yang belum berbadan hukum. Ayat (2), "Inventarisasi LKM sebagaimana dimaksud pada Ayat (1) harus diselesaikan paling lambat 2 (dua) tahun terhitung sejak undang-undang ini berlaku. Ayat (3), "dalam melakukan inventarisasi LKM sebagaimana dimaksud pada Ayat (1), Otoritas Jasa Keuangan, Kementrian yang menyelenggarakan urusan koperasi dan Kementrian Dalam Negeri dapat bekerjasama dengan pihak lain yang memiliki infrastruktur memadai. 
Analisis Normatif Undang-undang No. 1 Taun 2013

Hasan, di kantor Otoritas Jasa Keuangan (OJK) Kompleks Bank Indonesia, hari Jum'at, tanggal 11 Juli 2014, tentang koordinasi pelaksanaan UndangUndang No. 1 Tahun 2013 tentang Lembaga Keuangan Mikro (LKM). ${ }^{29}$

Dengan demikian, Undang-Undang No. 1 Tahun 2013 tentang Lembaga Keuangan Mikro (LKM) baru akan berlaku selambat-lambatnya 2 (dua) tahun sejak diundangkannya pada tahun 2013 dan sampai saat ini belum ada peraturan pelaksanaannya. Oleh karena itu, dalam hal pengawasan muncul keresahan di kalangan penggiat BMT, di mana Undang-Undang No. 1 Tahun 2013 tentang Lembaga Keuangan Mikro (LKM) ini dinilai akan mentransformasikan status kelembagaan BMT yang semula adalah koperasi di bawah pengawasan Kementrian Koperasi dan UKM menjadi bentuk bank yang nantinya akan diawasi oleh Otoritas Jasa Keuangan, karena perkembangan BMT yang semakin pesat diikuti dengan pemekaran cakupan wilayah BMT lintas kota/kabupaten, bahkan antar provinsi.

Jawaban dari pertanyaan-pertanyaan dan keresahan-keresahan tersebut akan terjawab setelah peraturan pelaksanaan dari Undang-Undang No. 1 Tahun 2013 tentang Lembaga Keuangan Mikro (LKM) ini sudah ada dan dilaksanakan. Sampai saat ini, masih berada pada tahap inventaris LKM-LKM berdasarkan status b adan hukumnya, apakah koperasi, perseroan terbatas atau yang tidak atau belum berbadan hukum.

\section{Kesimpulan}

1. Berdasarkan pembahasan di atas dapat disimpulkan bahwa, status badan hukum BMT dapat dikelompokkan menjadi 3 kelompok, yaitu : BMT yang berbadan hukum koperasi dalam bentuk Koperasi Jasa Keuangan Syariah dan tunduk pada Undang-Undang No. 25 Tahun 1992 tentang Perkoperasian dan pengawasannya tunduk pada Peraturan Menteri Koperasi dan UKM Nomor 39/Per/M.KUKM/XII/2007 tentang Pedoman Pengawasan Koperasi Jasa Keuangan Syariah dan Unit Jasa Keuangan Syariah Koperasi yang dilakukan oleh Dewan Pengawas Syariah (DPS) dan selanjutnya oleh Kementrian Koperasi dan UKM di mana

${ }^{29}$ Jobsmediaonline.com. Diunduh pada hari Rabu, tanggal 10 September 2014. 
domisili BMT berada, apabila di tingkat kota dilakukan oleh Dinas Koperasi dan UKM Kota/Kabupaten, sedangkan bila di tingkat provinsi, maka dilakukan oleh Dinas Koperasi dan UKM Provinsi. BMT yang berbadan hukum yayasan dan tunduk pada Undang-Undang No. 28 Tahun 2004 tentang Perubahan Atas Undang-Undang No. 16 Tahun 2001 tentang Yayasan, dan BMT yang masih berbentuk Kelompok Swadaya Masyarakat (KSM) dan tunduk pada Undang-Undang No. 17 Tahun 2013 tentang Organisasi Masyarakat.

2. Setelah berlakunya Undang-Undang No. 1 Tahun 2013 tentang Lembaga Keuangan Mikro, maka status badan hukum BMT sebagai lembaga keuangan mikro hanya dapat berbentuk koperasi atau perseroan terbatas. Bila berbentuk koperasi, maka tunduk pada Undang-Undang No. 25 Tahun 1992 tentang Perkoperasian dan pengawasan berada di bawah Kementrian Koperasi dan UKM. Dan jika berbadan hukum perseroan terbatas, maka pengawasan dilakukan Otoritas Jasa Keuangan dan tunduk pada Undang-Undang No. 21 Tahun 2011 tentang Otoritas Jasa Keuangan. Dilematika yang dialami BMT adalah permasalahan eksistensinya apabila mengembangkan usaha melebihi satu kabupaten/kota, maka harus bertransformasi menjadi bank dan berstatus badan hukum perseroan terbatas. Permasalahan transfromasi lembaga keuangan yang memiliki pengembangan di lebih dari 1 kabupaten/kota memiliki aturan yang tumpang tindih antara Undang-Undang Perkoperasian dan Undang-Undang Lembaga Keuangan Mikro. Dalam hal pengawasan, lembaga keuangan mikro diawasi dan dibina oleh tiga kementrian, yaitu Otoritas Jasa Keuangan (OJK), Kementrian Koperasi dan UKM dan Kementrian Dalam Negeri, sebagaimana nota kesepahaman yang telah ditandatangani oleh tiga kementrian tersebut.

\section{Rekomendasi}

Berdasarkan pembahasan di atas direkomendasikan kepada:

1. Pemerintah, dalam hal ini tiga kementrian yang telah menandatangani nota kesepahaman tentang pengaturan LKM, bahwa perlu adanya kejelasan fungsi dan tugas dan tangung jawab dari masing-masing kementrian yang 
Analisis Normatif Undang-undang No. 1 Taun 2013

tertuang dalam peraturan pelaksanaan yang jelas dan tegas yang mengatur standar operasional prosedur dan pelaksanaan kegiatan Lembaga Keuangan Mikro (LKM) serta dalam hal pembinaan dan pengawasan LKM, khususnya BMT yang memiliki karakteristik khusus dibandingkan LKM lainnya. Keberadaan BMT yang telah berbadan hukum koperasi, jauh sebelum Undang-Undang No. 1 Tahun 2013 tentang Lembaga Keuangan Mikro diundangkan dan telah memiliki aset yang cukup besar, dengan keluasan cakupan usaha di berbagai kabupaten/kota bahkan provinsi harus diatur dengan tegas proses transformasinya

2. OJK, Kementrian Koperasi dan UKM serta Kementrian Dalam Negeri, bahwa perlu adanya sosialisasi Undang-Undang LKM ini ke BMT-BMT dan stakeholdernya, agar eksistensi dan pembinaan serta pengawasan BMT ini semakin jelas, di bawah pertanggungjawaban kementrian apa. 


\section{DAFTAR PUSTAKA}

DSN MUI No. 07/DSN-MUI/IV/2000 tentang Pembiayaan Mudharabah (Qiradh)

DSN MUI No. 08/DSN-MUI/IV/2000 tentang Pembiayaan Musyarakah.

DSN MUI No. 04/DSN-MUI/IV/2000 tentang Murabahah,

DSN MUI No. 05/DSN-MUI/IV/2000 tentang Jual Beli Salam,

DSN MUI No. 06/DSN-MUI/IV/2000 tentang Jual Beli Istishna.

DSN MUI No. 09/DSN-MUI/IV/2000 tentang Pembiayaan Ijarah.

DSN MUI No. 27/DSN-MUI/III/2002 tentang Al-Ijarah Al-Mutabiyah bi AlTamlik.

DSN MUI No. 19/DSN-MUI/IX/2000 tentang al Qardh.

Jobsmediaonline.com. Diunduh pada hariRabu, tanggal 10 September 2014.

Joelarso, BMT Summit 2012, Yogyakarta, Universitas Gajah Mada, 7 November 2012.

Keputusan Menteri Negara Koperasi Dan Usaha Kecil Dan Menengah Republik Indonesia Nomor : 91/Kep/M.KUKM/IX/2004 Tentang Petunjuk Pelaksanaan Kegiatan Usaha Koperasi Jasa Keuangan Syariah Menteri.

Laporan Pembangun Sektor dan UMKM Dinas Koperasi Jawa Tengah Semester I Tahun 2014

Laporan Pembangun Sektor dan UMKM Semester I Tahun 2014

Majalah Warta Ekonomi Edisi No. 08/XXV/2013

Mughal, Muhammad Zubair, CEO Al Huda Center of Islamic Banking and Economics, internasional Conference "Empowering SMEs for Financial Inclusion and Growth", (Jakarta: 2014) 
Analisis Normatif Undang-undang No. 1 Taun 2013

Peraturan Menteri Koperasi dan UKM Nomor 39/Per/M.KUKM/XII/2007 tentang Pedoman Pengawasan Koperasi Jasa Keuangan Syariah dan Unit Jasa Keuangan Syariah Koperasi

Peraturan Menteri Negara Koperasi Dan Usaha Kecil Dan Menengah Republik Indonesia Nomor : 35.2/Per/M.Kukm/X/2007 Tentang Standar Operasional Prosedur KJKS

Pedoman Rumah Tangga DSN-MUI

Riyadi, Rahmat, "Konsep dan Stategi pemberdayaan LKMS di Indonesia", makalah disampaikan pada Seminar Nasional Kontribusi Hukum dalam Pemberdayaan LKMS, Fakultas Hukum Undip, Semarang, 18 Desember 2007.hal. 8 .

Undang-Undang Dasar Negara Republik Indonesia Tahun 1945

Undang-Undang No. 25 Tahun 1992 tentang Koperasi.

Undang-Undang No. 28 Tahun 2004 tentang Perubahan Atas UndangUndang No. 16 Tahun 2001 tentang Yayasan.

Undang-Undang No. 21 Tahun 2011 tentang Otoritas Jasa Keuangan (OJK).

Undang-Undang No. 17 Tahun 2012 tentang Perkoperasian

Undang-Undang No. 1 Tahun 2013 tentang Lembaga Keuangan Mikro

Undang-Undang No. 17 Tahun 2013 tentang Organisasi Kemasyarakatan. 